\title{
Presencia femenina en la travesía de Odiseo: estudio iconográfico
}

\author{
Mercedes Aguirre *
}

\section{RESUMEN ABSTRACT}

En la travesía de Odiseo rumbo a ítaca tras la guerra de Troya, los personajes femeninos (diosas o mujeres mortales) tienen un papel muy significativo. De ellas unas se muestran benévolas con el héroe, como la diosa Atenea o la joven princesa Nausica, otras son auténticas femmes fatales que intentan impedir al héroe el regreso al hogar.

Sin embargo, Circe y Calipso presentan una doble cara: peligrosas al principio, van a resultar después de gran ayuda. Pero siempre peligrosas son las monstruosas Escila, Caribdis o las Sirenas. Las imágenes en el arte griego de estas figuras femeninas nos muestran cómo los artistas no siguieron siempre la tradición homérica sino que pudieron inspirarse en otras leyendas relativas al mar y a la travesía del héroe Odiseo y ello explicaria las ocasionales divergencias entre los textos y las imágenes.
On Odysseus' return to lthaca after the Trojan war, female characters (goddesses or mortal women) have a very significant role. Some of them show a benevolent attitude towards the hero, like Athena or the young princess Nausicaa; the others are femmes fatales who attempt to detain the hero on his journey to his homeland. However, Circe and Calypso are double faced: they are first dangerous, next very helpful; but the monsters Skylla, Charybdis and the Sirens are always dangerous.

The representations in Greek Art of these female figures show how artists were not always inspired by Homeric tradition, but they could have sought inspiration from other legends related to the sea and Odysseus journey, and that would explain the occasional contradictions between texts and images.

* Dpto. de Filología Griega. Facultad de Filología. Universidad Complutense. 
En la Odisea de Homero, el poema que recoge las aventuras del héroe Odiseo o Ulises rumbo a su patria ítaca, aunque es él, el hombre, el protagonista, las figuras femeninas tienen un destacado y muy significativo papel en torno al héroe. Dejando de lado a la fiel Penélope, su esposa, y a aquellas mujeres relacionadas con su hogar (su nodriza Euriclea o las sirvientas), quiero detenerme en esas diosas o simples mujeres mortales que salen a su encuentro o intervienen en los distintos episodios de su travesía. $Y$ voy a distinguir en ellas tres grupos diferentes según la actitud que muestran hacia el héroe, viendo a la vez cómo han sido representadas por los artistas griegos.

En primer lugar tendríamos aquellas que están a su lado y son benévolas con él de alguna manera. Comenzando por la diosa Atenea, su incondicional protectora, como lo es asimismo de otros héroes: de Teseo fundamentalmente por ser el héroe de la ciudad de Atenas de la que es la diosa la patrona, pero también de Perseo en sus aventuras.

Atenea, según la Odisea, acompaña y protege a Odiseo y a su hijo Telémaco. Interviene ante su padre Zeus, el soberano de los dioses. Se aparece en sueños a Nausica. Toma la apariencia de aquello que desea. Transforma al héroe haciéndolo más viejo o más joven según lo requiera el momento. Le aconseja... Numerosos pasajes del poema nos ofrecen testimonio de ello:

«Padre Cronida... es por el prudente Odiseo por quien se acongoja mi corazón, por el desdichado que lleva ya mucho tiempo lejos de los suyos y sufre en una isla rodeada de corriente donde está el ombligo del mar». Od. 1.48-50.

“Entonces le concedió Atenea, la hija de Zeus, aparecer más apuesto y robusto... así Atenea vertió su gracia sobre la cabeza y hombros del divino Odiseo». Od. 6. 229-235.

Pero a pesar de la importancia de la diosa en el poema como especial amiga y ayudante del héroe, sin embargo, sólo en las representaciones del episodio de Nausica encontramos alguna imagen suya que refleja esa especial atención que muestra Atenea por su protegido.

$Y$ ya podemos citar también a Nausica como una mujer, en este caso mortal, que es benévola a nuestro héroe. La joven y dulce Nausica que le encuentra en la playa mientras ella y sus doncellas están jugando a la pelota. Pero no por casualidad, pues la diosa Atenea le ha inspirado que vaya a la orilla del mar con sus sirvientas para lavar la ropa; $y$, mientras, Odiseo, tras una tempestad que hizo naufragar su balsa, ha conseguido llegar exhausto hasta la costa donde lo encuentia ella, semidesnudo, cubierto de 
sal. La muchacha no siente vergüenza ante aquel apuesto desconocido que probablemente despierta en su corazón toda clase de sentimientos encontrados. Ella le salva la vida y quisiera que fuese su esposo, pero no puede ser... Aún así Nausica le indicará cómo llegar al palacio de su padre Alcínoo en donde encontrará Odiseo la ayuda que necesita para volver a su patria. $Y$ cuando llega al fin el momento de la partida, la joven dedica al héroe una tierna frase de despedida:

"Salud, huésped, acuérdate de mí cuando estés en tu patria pues es a mí la primera a quien debes la vida». Od. 8.461-462.

El episodio de Nausica, a pesar de su encanto, encontró poco eco en el arte griego y no hay imágenes anteriores al siglo $v$ a.C. ${ }^{1}$ De las que tenemos, incluso, algunas son dudosas. Quizá ello se debe a que los detalles eran menos significativos y llamaron menos la atención que los de otros episodios.

Un ánfora ática de figuras rojas procedente de Vulci (fig. 1) representa a Odiseo desnudo acercándose suplicante a un grupo de muchachas con una rama en cada mano. Atenea está delante del héroe con el rostro vuelto hacia él. Tras Odiseo hay un árbol de cuyas ramas cuelga la ropa que se

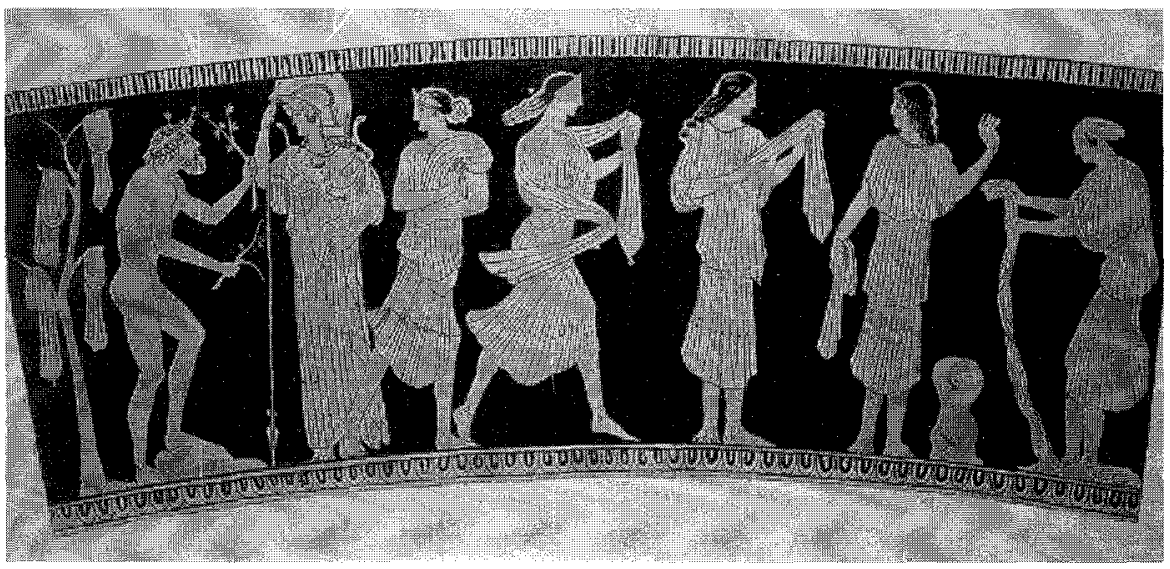

Fig. 1. Ánfora ática de figuras rojas procedente de Vulci. (440-430 a.C.). Munich, Gliptoteca. Odiseo, Atenea y las jóvenes lavando y tendiendo la ropa.

\footnotetext{
PaUSANIAS (1.22.6) nos da testimonio de una pintura de Polignoto - hoy perdida - representando la escena de Odiseo, la princesa Nausica y las jóvenes lavando la ropa en el río. Quizá los testimonios que poseemos en vasos áticos estén influenciados por esta pintura.
} 
está secando y las muchachas llevan la ropa que están lavando y tendiendo, aunque no podemos saber cuál de ellas es Nausica.

Un pixis ático de figuras rojas (fig. 2) nos ofrece una escena similar con Odiseo desnudo y delante de él Atenea y cuatro muchachas en distintas posturas ocupadas en lavar la ropa; de ellas quizá la que lleva el vestido más adornado sea Nausica.

Hay quien piensa que algunas de estas imágenes de Nausica con las jóvenes lavando la ropa, Atenea y Odiseo pudieran estar inspiradas no en la Odisea sino en una obra perdida de Sófocles titulada Nausica, ya que esta escena no coincide con el poema homérico pues las mujeres ya han secado la ropa cuando aparece Odiseo ${ }^{2}$. Sin embargo, ese desajuste podría deberse a algo habitual en el arte griego que es el condensar varias escenas distintas en una única imagen.

En un segundo grupo incluimos a aquellas figuras femeninas que podríamos llamar «ambivalentes», que suponen un peligro para el héroe pero que al final pueden resultarle de ayuda, de gran ayuda incluso. Éstas serían Circe y Calipso.

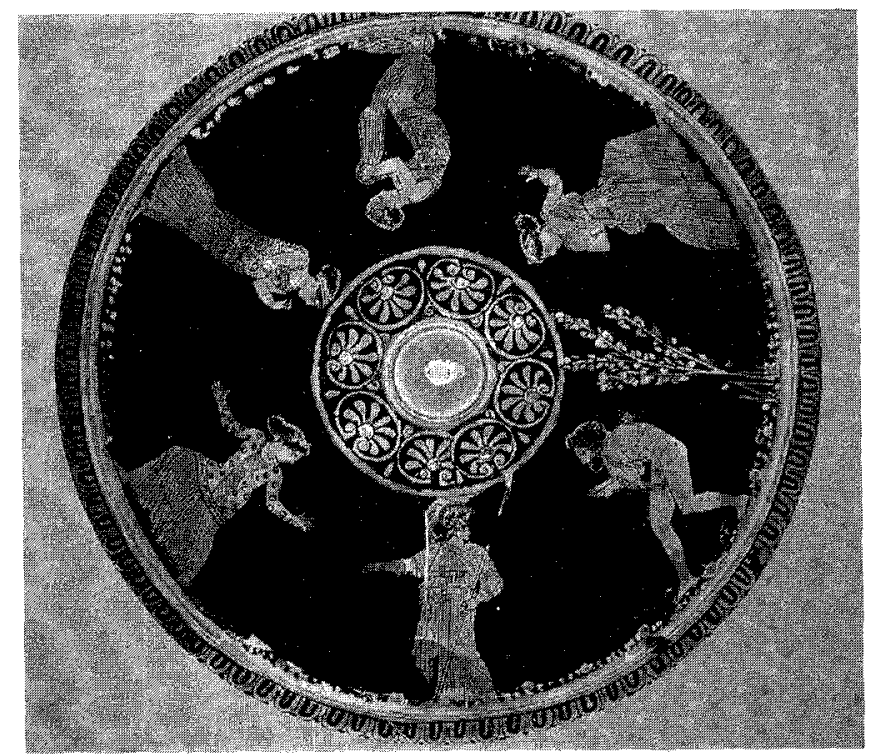

Fig. 2. Pixis ático de figuras rojas (ca. 430 a.C.). Boston, Museo de Bellas Artes. Odiseo, Atenea y cuatro jóvenes lavando la ropa.

2 Cf. A.D.Thendall-T.B.L.Webster, Illustrations of Greek Drama, Londres 1971, pág. 66. 
Las dos intentan impedir a Odiseo el regreso a su patria, pero a la vez son amorosas con él y acogen al héroe en su morada con toda clase de atenciones. Circe, la hechicera, con sus artes mágicas ha encantado a sus compañeros transformándolos en cerdos, pero fracasa en su propósito de hacer lo mismo con él. Luego, tras retenerle todo un año a su lado, le ayudará con sus recomendaciones a salir con éxito de los peligros que le aguardan en su navegación hasta Ítaca. Calipso, la bella ninfa, tras siete años de amor no correspondido y tras ofrecerle la inmortalidad que el héroe rechaza, colaborará con él en la preparación de su partida.

Ambas le rodean de toda clase de comodidades como si fuera un inmortal pero jay! todo ese encanto y belleza tiene su lado oscuro y terrible. Si Odiseo se queda con ellas... no regresará nunca a su hogar.

Son bellas. Y así nos las describe Homero: son «la de hermosas trenzas», «la de ojos brillantes», pero no están exentas de un lado peligroso. Se encuentran alejadas del mundo normal de los dioses Olímpicos y el encuentro con ellas puede ser dulce y placentero pero es fatal para un ser humano.

La pérfida bruja Circe o la oculta Calipso, con su fachada de belleza y seducción pueden resultar, como ya he dicho, terribles para el héroe. Pero al final las cosas cambian y ambas se tornan benévolas, amables y, vencidas por poderes superiores a ellas, tienen que consentir ver partir a su amado ${ }^{3}$.

El episodio de Circe es el más representado de todos los de la Odisea después del de Polifemo. Ya desde el siglo vı a.C. pintores, escultores y orfebres han encontrado en él inspiración para sus obras. En cuanto a la fidelidad de las imágenes con el texto homérico debemos notar que son los detalles más significativos o más llamativos los que aparecen más repetidamente representados: Circe con el recipiente del bebedizo mágico o la metamorfosis de los compañeros. Aunque esta metamorfosis no suele ser completa pues encontramos seres humanos con cabeza de animal y no exclusivamente de cerdo sino también de otros animales. No hay nada en ella que muestre su carácter divino ni se representa la situación geográfica de su lejana isla; todo es bastante impreciso ${ }^{4}$. El palacio donde habita no aparece, si acaso algún objeto de mobiliario, y una vez que se la representa en una gruta parece haber una confusión con Calipso pues es ésta y no Circe la que vive en una cueva.

3 Cf. mis trabajos «El tema de la mujer fatal en la Odisea», CFC 4, 1994, 301-317. y "Ambigüedad y otros caracteres en las divinidades remotas de la épica arcaica», CFC, 6, 1996, 143-157.

4 Cf. O.Touchefeu Meynier, Thèmes Odysséens dans l'art antique, París 1968, pág. 116. 
Una copa ática de figuras negras (fig. 3) nos muestra una Circe desnuda en el centro de la escena mezclando su pócima y ofreciéndosela a un griego. Está rodeada de los compañeros de Odiseo que tienen cabeza de animal y cuerpo humano. Los animales no son únicamente cerdos sino también pantera, cabra, león, caballo y gallo. No es fácil explicar el hecho de que Circe aparezca aquí desnuda - lo mismo que en algunas otras representaciones-, pues no es frecuente representar así a una diosa. Es posible que de esta manera se estén queriendo indicar las relaciones sexuales que va a tener después con el héroe ${ }^{5}$; o es una forma de resaltar ese carácter especial que la distingue de otras figuras femeninas. A los pies de la diosa hay un perro y Odiseo está mezclado entre sus compañeros con la espada desenvainada. Por tanto, como es habitual en la pintura de vasos, se están representando a la vez dos momentos del episodio: el de la metamorfosis y el de la amenaza de Odiseo.

Un skyphos de figuras negras de estilo cabirio (fig. 4) nos muestra la escena de Odiseo frente a Circe de pie que lleva un gran vaso en las manos, pero aquí ambos personajes son un tanto grotescos: nariz chata, labios gruesos, cuerpos deformes. A la derecha del héroe hay un telar en el que - según el poema- la diosa estaba ocupada cuando llegan los griegos. La escena se completa por la derecha con la figura de uno de los compañeros transformado

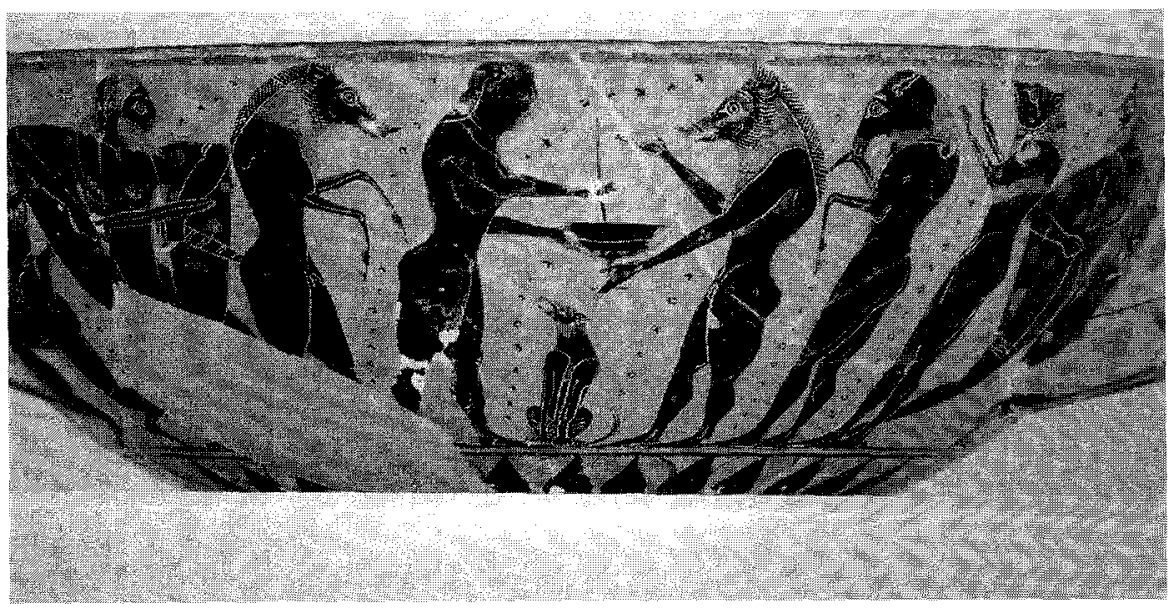

Fig. 3. Copa ática de figuras negras de mediados del siglo vi a.C. Boston, Museo de Bellas Artes. Circe rodeada de Odiseo y sus compañeros.

5 Cf. A.SHAPIRO, Myth into Art, Londres/Nueva York 1994 y D.BuItron-B.COHEN, The Odyssey and Ancient Art: An epic in Word and Image, Annandale on Hudson 1992. 


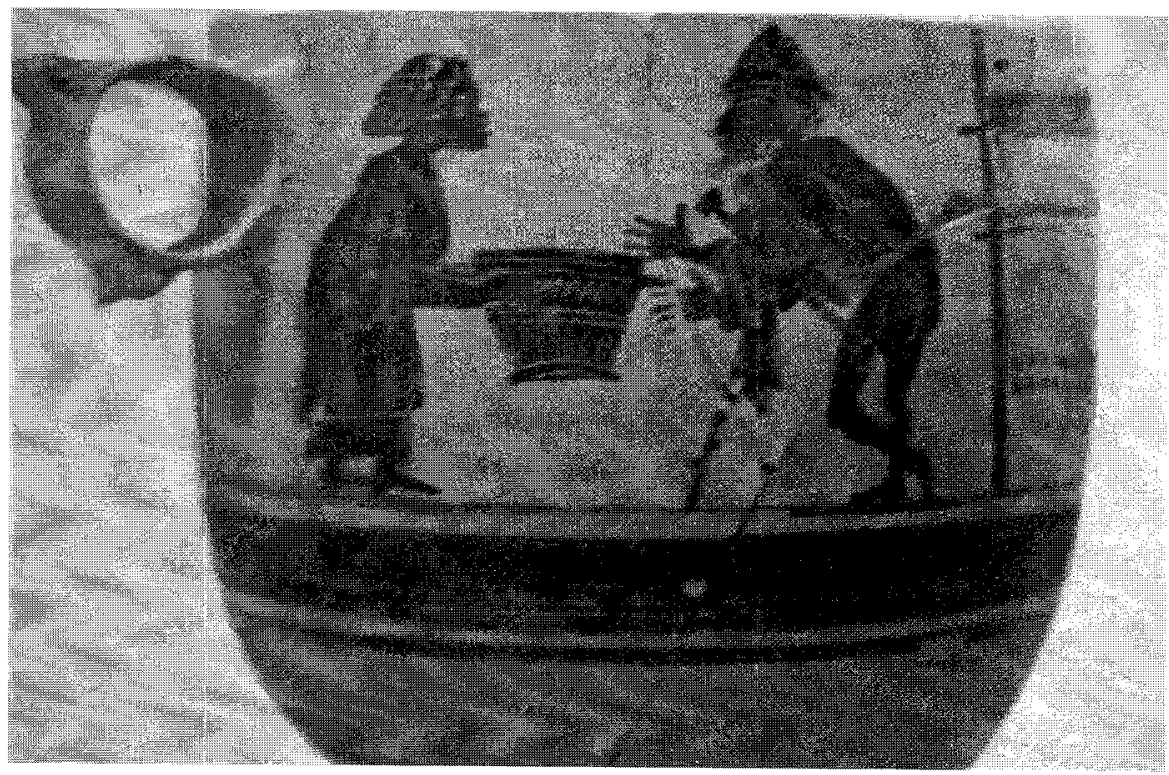

Fig. 4. Skyphos de figuras negras (finales del siglo v a.C.). Londres, Museo Británico. Odiseo y Circe.

en un jabalí cuya metamorfosis parece completa salvo las piernas que parecen humanas porque son demasiado largas al estar sentado como un animal. Es interesante notar que los ojos de Odiseo y Circe están pintados de perfil y no de frente como suele ocurrir cuando las figuras están de perfil.

Otro skyphos de figuras negras (fig. 5) nos muestra una escena muy semejante con las figuras de Odiseo y Circe también con aspecto grotesco ${ }^{6}$. Aquí Odiseo parece aterrorizado ante la pócima que Circe le presenta. Tras ellos también aparece un telar.

Algunos de los detalles que aparecen en las representaciones de este episodio parecen de procedencia no homérica, por ejemplo los hombres convertidos en distintos tipos de animales cuando se nos dice expresamente en la Odisea que fueron convertidos en cerdos ¿Quizá porque momentos antes de esta escena se nos habla de otros animales que rodean a Circe y se supone que eran otros hombres metamorfoseados? También hay algunas representaciones, sobre todo en el arte etrusco, en las que

6 Para H.B. WALters ( Odysseus and Kirke on a Boeotian vase», JHS 13, 1892-93, 77-87) parece claro que existe una intención caricaturesca en este vaso así como en el anterior. 


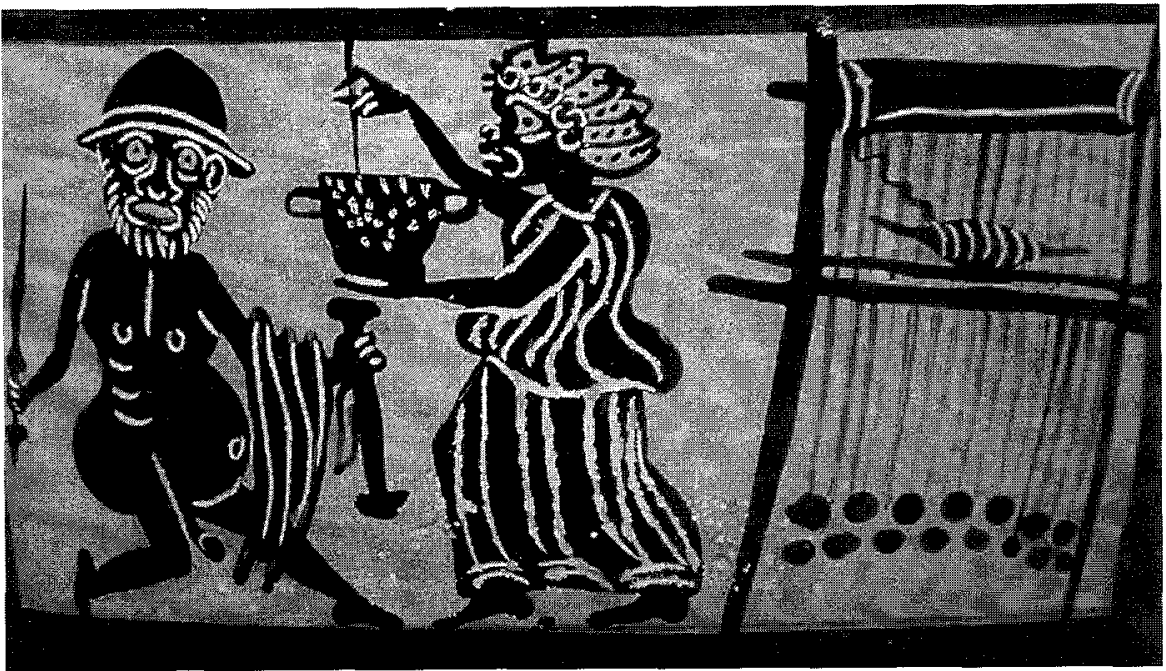

Fig. 5. Skyphos de figuras negras (s. N-III a.C.). Oxford, Ashmolean Museum. Odiseo y Circe.

los griegos se divierten con su nuevo aspecto animal y parecen hostiles a Odiseo ${ }^{7}$. Estos detalles podrían proceder de otras tradiciones sobre el mito o bien haber sido creados por los artistas interpretando a su modo el episodio. Por otro lado, algunas de las representaciones de carácter cómico o burlesco podrían estar inspiradas en un drama satírico perdido ${ }^{8}$.

De Calipso, la hermosa ninfa con la que Odiseo pasa siete largos años antes de volver al fin a su patria no existe ninguna representación clara en el arte griego. Touchefeu-Meynier cita algunas dudosas ${ }^{9}$, por ejemplo un ánfora de Melos en la que podría estar representada la escena de Hermes visitando a Calipso (fig. 6).

Por último podemos citar a las figuras femeninas que son claramente peligrosas, que suponen un grave riesgo para el héroe aunque al final

Cf. O. TOUCHefEu MeYnier, o.c., págs.122 ss. y O. Touchefeu Meynier, «Ulysse ef Circé: notes sur le chant $\mathrm{X}$ de l'Odyssée», REA, 63, 1961 pág. 266.

8 Cf. O. TOUCHEFEu MEYNier, Thèmes..., pág. 116 ss. Es interesante la presencia de esta escena cómica de Odiseo y Circe en estos vasos procedentes del santuario tebano de los Cabiros, divinidades honradas especialmente en Samotracia con afinidades con el dios Dioniso. Para algunos autores esta hecho parece sugerir una relación con los Misterios de Eleusis y nos presentaría el encuentro entre Odiseo y Circe con ciertas reminiscencias de rito de iniciación (cf. H.B. WALters, O.C. Y J.M. MORET, "Circé tisseusse sur les vases du Cabirion", RA 1991, 227266).

Thèmes..., 192 ss. 




Fig. 6. Ánfora de figuras negras procedente de Melos (ca. 600 a.C.). Atenas, Museo Nacional. Hermes y Calipso.

Odiseo consiga también salir indemne de su encuentro con ellas, aunque no lo habría logrado sin las advertencias previas de Circe.

No son ya seres completamente humanos sino monstruosos, o bien, aunque su apariencia física no sea descrita por Homero, en cualquier caso su carácter no deja lugar a dudas.

Cuando Circe advierte a Odiseo los peligros que va a correr cuando abandone su isla, las recomendaciones son claras ${ }^{10}:$ su nave tendrá que pasar entre dos escollos, tan altos que llegan hasta el cielo, donde habitan dos terribles seres: Escila y Caribdis. La una es un horrible monstruo de doce pies y seis cuellos terminados en otras tantas cabezas cuyas bocas están provistas de afilados dientes; la otra una insaciable criatura que engulle todo cuanto encuentra. $Y$ en su paso, la nave de Odiseo debe acercarse más a Escila pues, aunque pierda a alguno de sus hombres, Caribdis sería fatal para todos. Pero no debe el héroe intentar luchar con ella ya que es inmortal y no podría vencerla.

${ }_{10}$ Od. 12.73- 10 
La descripción homérica del monstruo Escila es clara y detallada. Sin embargo, en el arte griego arcaico no existen representaciones suyas ni de este episodio. Las imágenes de Escila comienzan a aparecer a mediados del siglo $v$ a.C., pero en ellas tiene un aspecto totalmente diferente, pues es representada como un torso de mujer con una larga y enroscada cola de pez y unas cabezas de perro saliendo de su cintura. Esta es asimismo la Escila de los testimonios literarios tardíos según los cuales su aspecto híbrido se debería a los celos de Circe ${ }^{11}$.

Un relieve de terracota melio (fig. 7) nos muestra a Escila de perfil vestida su parte femenina con un quitón y terminada en una cola de pez 0 serpiente marina enroscada. Dos torsos de perro salen de su cintura.

Con ese mismo aspecto aparece frecuentemente representada en monedas del sur de Italia, monedas procedentes de ciudades relacionadas con el estrecho de Mesina que era el lugar donde tradicionalmente se situaba la cueva donde habitaba el monstruo.

En estas imágenes y en otras de aproximadamente la misma época no se asemeja en nada como ya he dicho al monstruo descrito por

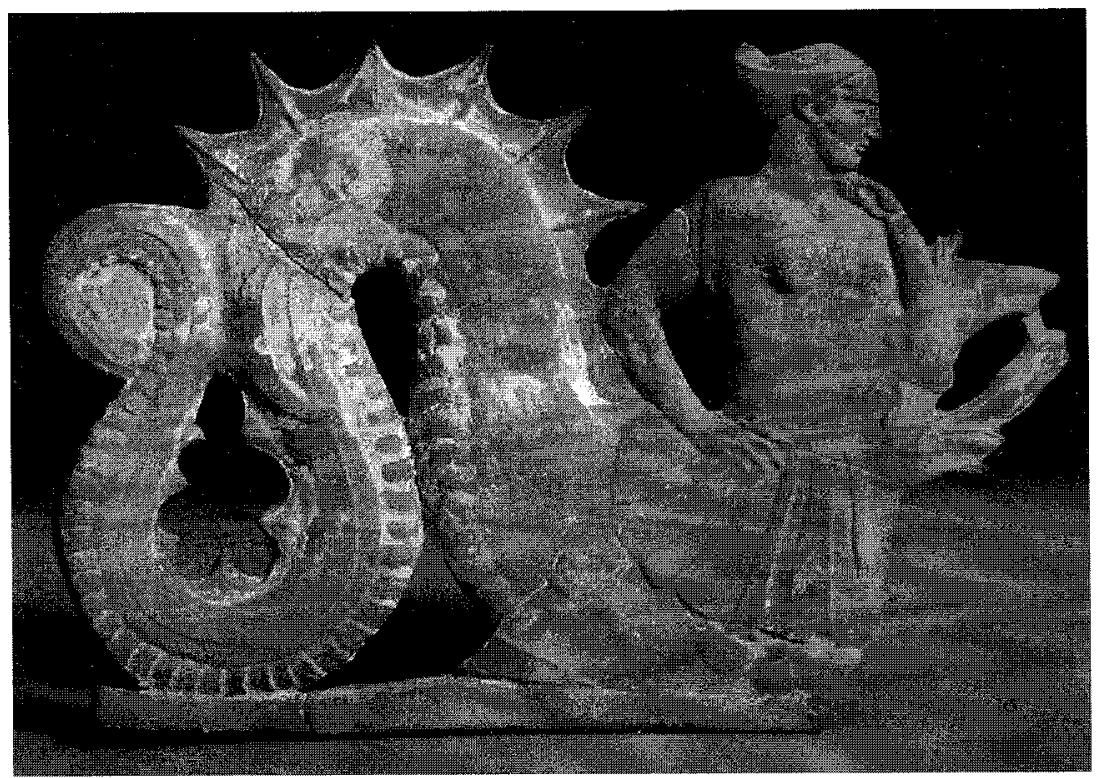

Fig. 7. Relieve de terracota procedente de Melos (s.v a.C.). Londres, Museo Británico. Escila.

11 Por ejemplo en Higinio Fab.199. 
Homero. El único detalle de los perros en su cintura podría hacernos recordar que el poeta nos dice que su aullido es como el de un cachorro recién nacido (Od. 12.86). Aquí representa el mar y los seres que en él habitan; por eso se la suele rodear de otras criaturas marinas como peces, cangrejos, tritones, nereidas etc. Asimismo ella puede llevar en sus manos algunos elementos relativos al mar: un tridente, un timón. Ha perdido por tanto su carácter peligroso; más bien al contrario, parece tan benévola como una nereida, incluso en ocasiones podría parecer una especie de guía para los marineros. Figura además a veces en imágenes de otros mitos que nada tienen que ver con el episodio de Odiseo y sus compañeros enfrentándose a ella en su nave, así en una representación de Europa sobre el toro (fig. 8) o en otra de Perseo liberando a Andrómeda.

A partir de época helenística encontramos una imagen diferente de Escila: es también una figura híbrida, pero ahora es representada más frecuentemente de frente con dos colas de pez enroscadas una a cada lado. Estas imágenes suelen aparecer en ciertos objetos como espejos o tapaderas así como posteriormente en mosaicos y grupos escultóricos ya en

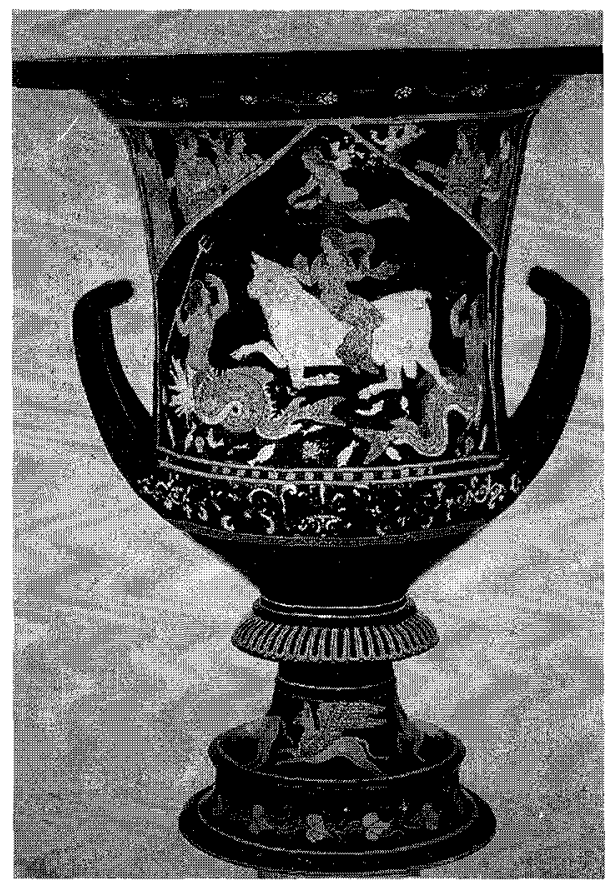

Fig. 8. Cratera de Paestum (ca. 340-330 a.C.). Malibú, Museo J.P.Getty. Europa sobre el toro. Abajo, Escila y otras criaturas marinas. 
época romana como en el bien conocido de la gruta de Tiberio en Sperlonga. En ellas Escila puede tener ya un aspecto agresivo intentando golpear con una piedra o un remo a una víctima humana y puede aparecer ya la escena completa de la nave de Odiseo.

Esta diferencia entre las representaciones artísticas de Escila y su más antigua fuente literaria podría ser debida a que pintores, escultores etc. evitaban representar los monstruos y seres desagradables. $O$ bien se trataría de una tradición diferente a la que recoge la Odisea ${ }^{12}$.

En cuanto a Caribdis, los artistas griegos no parecen haber sido capaces de plasmarla. Un monstruo indeterminado, un remolino que engulle el agua para después expulsarla no es fácil de representar. Pero un detalle que cita Homero, la higuera junto a su gruta, sí aparece en ocasiones representada. Hay autores que piensan que tiene relación con este episodio la imagen de un skyphos de finales del siglo vı (fig. 9) donde aparece un hombre sobre una tortuga, una higuera y una cavidad. Sin embargo habría un desajuste

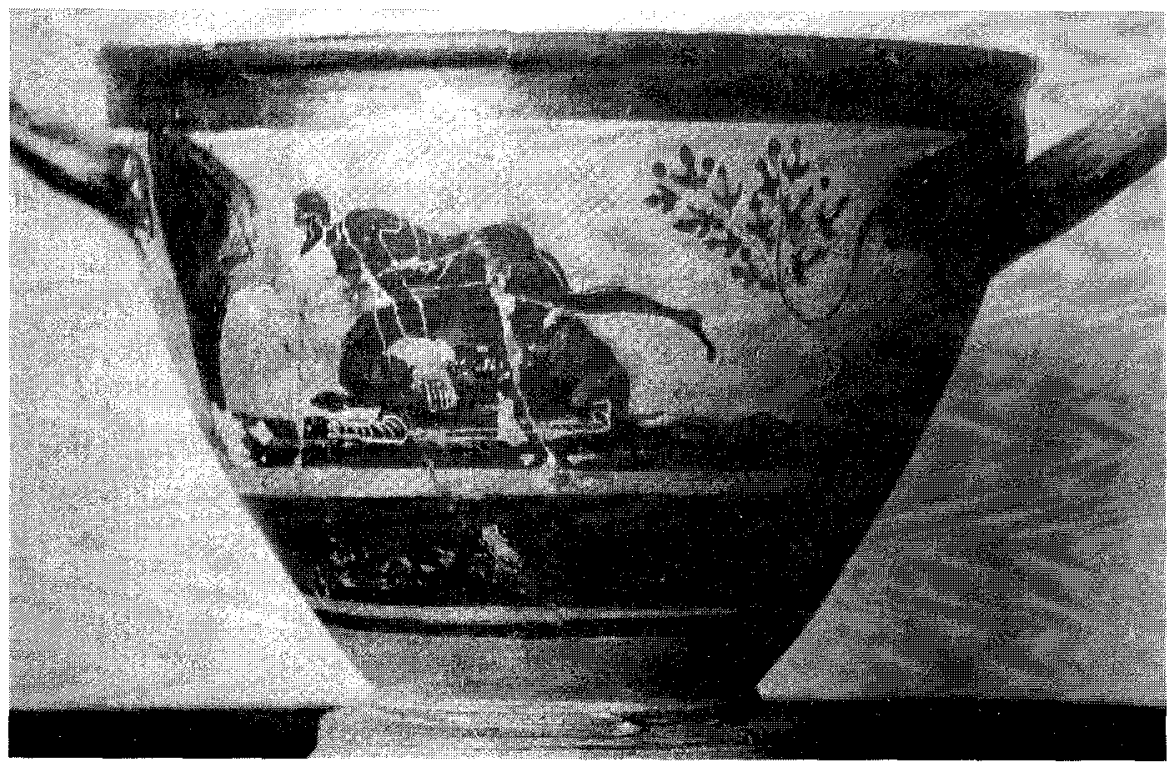

Fig. 9. Skyphos de figuras negras (s. w a.C.). Palermo, Museo Arqueológico. Un hombre sobre una tortuga, quizá Odiseo escapando de Caribdis.

12 La figura de Escila y sus representaciones artísticas está siendo objeto por mi parte de un estudio más amplio que será publicado próximamente, por ello solamente me detengo aquí en los aspectos más importantes. 
con el poema pues no es sobre una tortuga sino sobre un madero de su propia nave donde Odiseo se salva de ser engullido por Caribdis. Según algunos autores este tipo de representación sugiere la existencia de una leyenda alternativa que describe a los habitantes del mar amistosos con el héroe.

Finalmente incluimos en este grupo de seres femeninos peligrosos a las Sirenas. En dos ocasiones nos habla Homero de las Sirenas. Por un lado, la maga Circe advierte a Odiseo el peligro que éstas representan para los navegantes y le hace una serie de recomendaciones para salir ileso del encuentro con ellas. Y poco después se nos narra el encuentro mismo ${ }^{13}$. Las Sirenas, ciñéndonos al testimonio de Homero, son dos figuras femeninas indeterminadas - pues no se nos describe su aspectoque viven en una prado florido rodeadas de un montón de huesos de sus víctimas. Desde allí atraen a los navegantes con su dulce y hermosa voz que les incita a escuchar eternamente su canto, tentándoles además con su conocimiento del pasado, presente y futuro.

Se ha escrito mucho sobre las Sirenas, sobre su origen, su carácter y su aspecto y hay puntos bastante discutidos, por ejemplo cómo mueren sus víctimas o cuál era realmente su apariencia física para Homero ${ }^{14}$. En cualquier caso lo que sí está claro es que se trata de criaturas malignas, que representan los peligros del mar para los navegantes. También son ya, sin duda, eróticamente encantadoras, tal como nos las presentan las posteriores versiones de ellas en la literatura popular y que es como la idea de sirena ha llegado hasta nosotros.

Las Sirenas en el arte aparecen inicialmente como figuras aisladas, sin tener nada que ver con el episodio homérico. Son pájaros de cabeza humana empleados decorativamente desde finales del siglo vill a.C. Fueron también identificadas o confundidas con las Harpías, otros seres míticos de forma femenina con alas de ave que se encargaban de llevar las almas de los mortales al Hades.

La primera vez que se identifican con la Odisea es en la cerámica corintia del siglo vi a.C. como en un aríbalo corintio (fig. 10) en el que aparece representada la nave de Odiseo sobrevolada por dos enormes aves. En ella se encuentra el héroe atado al mástil y algunos de sus compañeros remando. Las Sirenas son tres y están situadas sobre una roca.

\footnotetext{
13 Od. $12.39-54$ y Od. $12.166-200$.

14 Entre los numerosísimos trabajos sobre ellas podemos citar: P. Rossı, «Sirènes antiques. Poesie, philosophie, iconographie», $B A G B, 1970,473-481$; G.K.Gresseth, «The Homeric Sirens", TAPhA, 1970, 203-218; E. HOFSTETTER, Sirenen in archaischen und klassischen Griechenland, Würzburg 1990.
} 


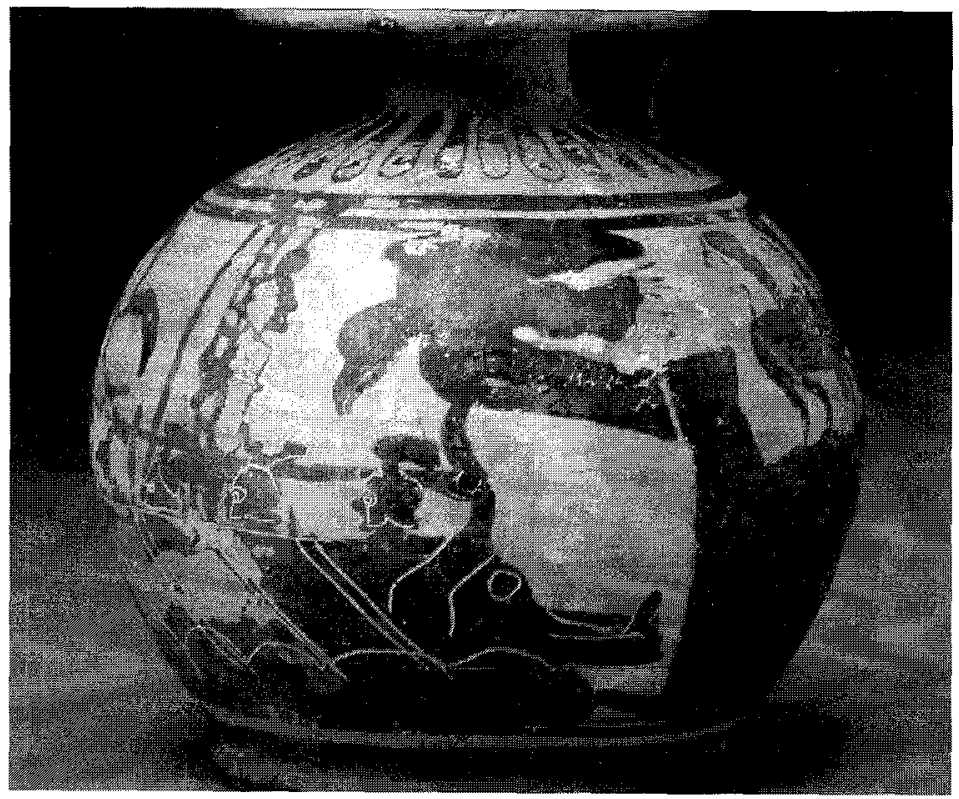

Fig. 10. Aríbalo corintio (s. vi a.C.). Boston, Museo de Bellas Artes. La nave de Odiseo pasando junto a las Sirenas.

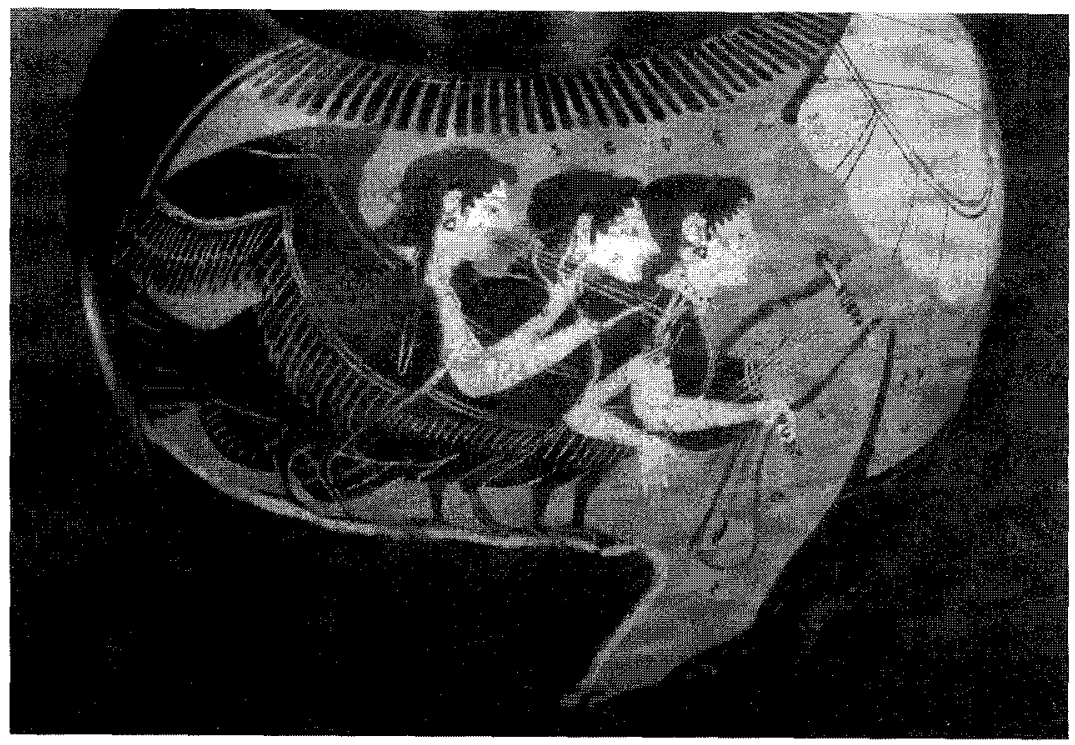

Fig. 11. Enócoe de figuras negras (s. vi a.C.). Nueva York, Colección Callimanopoulos. Tres Sirenas con instrumentos musicales. 
Este episodio de Odiseo y las Sirenas va a gozar de una gran popularidad y los artistas griegos van a utilizarlo frecuentemente en sus obras, por eso contamos con numerosas representaciones. En ellas los detalles suelen coincidir con el texto homérico, por ejemplo el que el héroe aparezca atado al mástil mientras sus compañeros reman, las velas plegadas y el barco alejándose del lugar donde ellas se encuentran sin que éstas lo persigan. No coincide en cambio su apariencia física ya que, como ya he dicho, Homero no nos da ninguna indicación sobre su aspecto, sólo alude al hechizo de su voz. Tampoco se representa la pradera florida ni su naturaleza peligrosa. A veces, las Sirenas aparecen con brazos, cuando éstos les son necesarios porque lleven algún instrumento musical. Como en el enócoe de figuras negras del siglo vi a.C. (fig. 11) que nos ofrece tres Sirenas con rostro de mujer y cuerpo de ave tocando música.

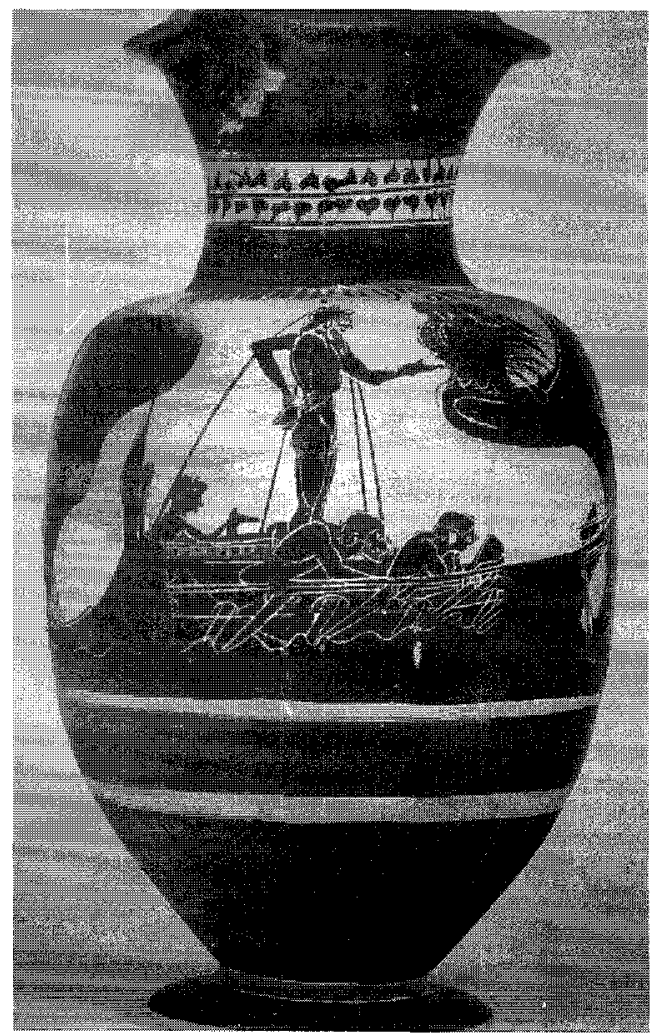

Fig. 12. Enócoe de figuras negras (s. vi a.C.). Berlín, Colección de Antigüedades. Odiseo frente a las Sirenas. 
En otro enócoe de figuras negras del mismo siglo (fig. 12) aparece Odiseo atado al mástil de su nave frente a la roca donde se encuentran tres Sirenas.

Asimismo en un lecito de figuras negras sobre fondo amarillo de fines del siglo VI a.C. (fig. 13) vemos representadas dos Sirenas con las alas plegadas, brazos femeninos y cabellera larga tocando música; Odiseo está atado a una columna jónica que simboliza el mástil de la nave.

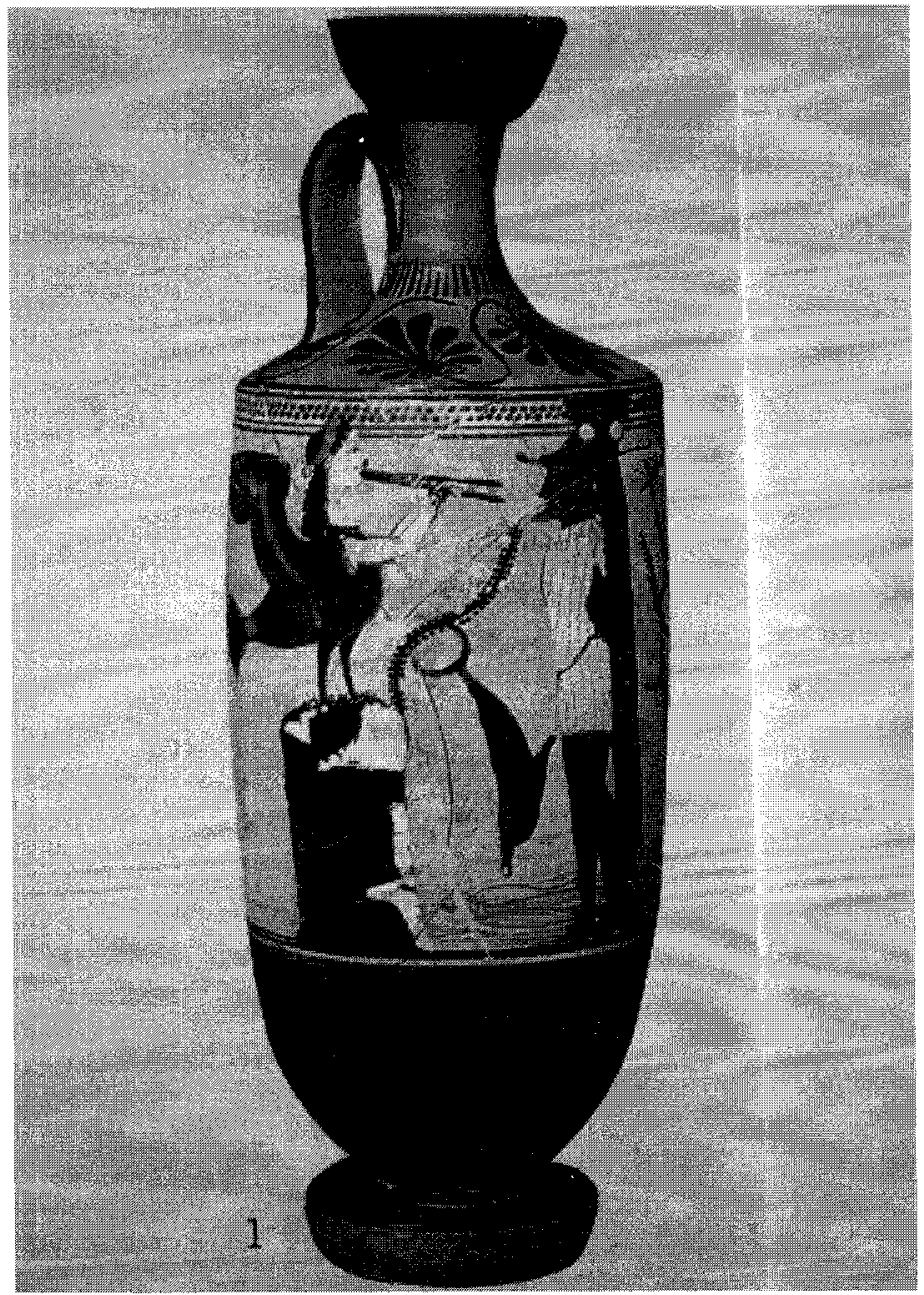

Fig. 13. Lecito de figuras negras (fines del s. vi a.C.). Atenas, Museo Nacional. Odiseo atado a una columna frente a una Sirena. 
Un stamnos ático de figuras rojas procedente de Vulci (fig. 14) nos presenta a Odiseo atado al mástil de su nave mientras pasa junto a las rocas donde se encuentran las Sirenas. De éstas una está cayendo al mar simbolizando quizá el hecho de que según el mito las Sirenas morirían si alguien lograba vencerlas ${ }^{15}$.

Una cratera de Paestum (fig. 15) ofrece una escena bastante curiosa y un tanto cómica con un Odiseo atado de frente al mástil con las manos delante y por encima de sus compañeros. Dos Sirenas, una a cada lado, tienen torso femenino adornado con joyas y cuerpo de ave. En una de sus manos llevan un instrumento musical.



Fig. 14. Stamnos ático procedente de Vulci (s. v a.C.). Londres, Museo Británico. Odiseo en su nave y tres Sirenas.

15 Cf. LICOFRÓN, Alex.5. 712-716. 


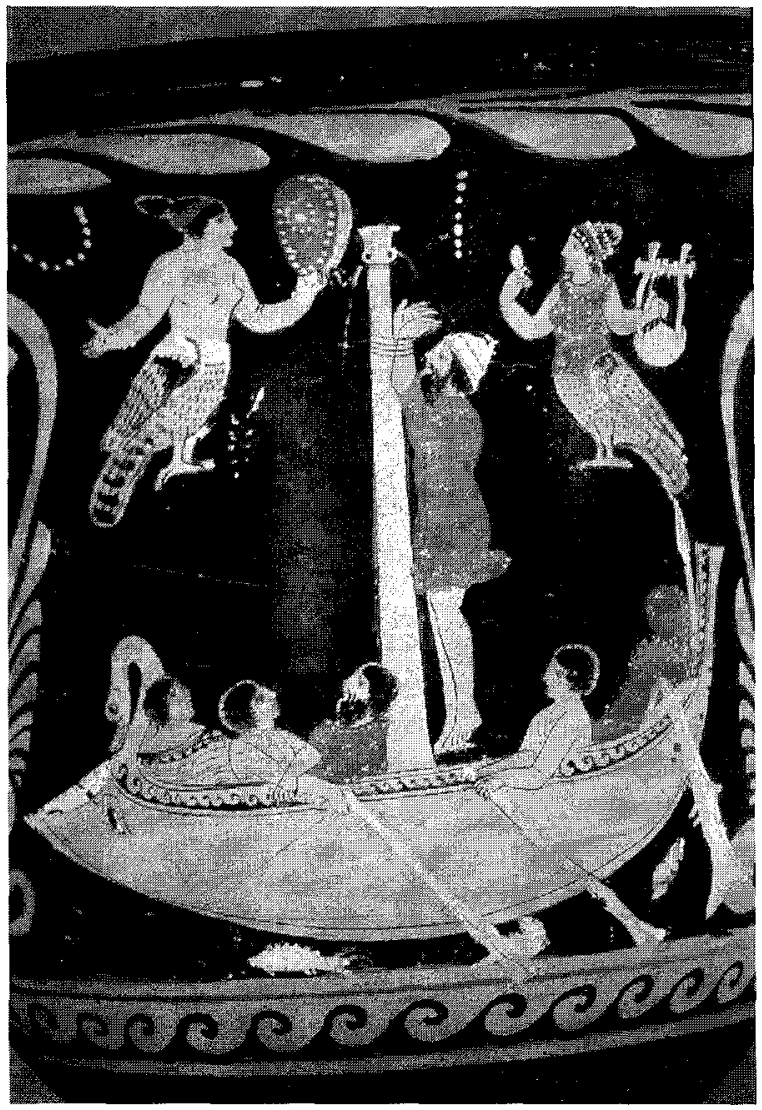

Fig. 15. Cratera de Paestum (ca.350 a.C.). Berlín, Colección de Antigüedades. Odiseo atado al mástil de su nave y dos Sirenas.

Hemos visto pues que las representaciones artísticas de esta serie de mujeres - divinas o humanas - en unos casos coinciden plenamente con lo que el texto nos dice de ellas —o al menos nos permite deducir-; en otros en cambio existe una total divergencia. La razón que se suele argumentar para explicar este hecho es que los artistas pudieron no seguir la tradición homérica sino otras leyendas relacionadas con el mar y la travesía marítima del héroe Odiseo en lás que los detalles podrían ser diferentes ${ }^{16}$. Algunas de estas leyendas paralelas pudieron también ser fuente de

16 Cf. entre otros R.M. CooK, "Art and Epic in Archaic Greece», BA Besch. 58, 1983, 1-10. 
inspiración para dramaturgos dando lugar a obras (tragedias, dramas satíricos) sobre estos mismos temas que nosotros hoy no conservamos pero que sí podrían conocer bien los artistas plásticos. De estos episodios, unos han gozado de una gran aceptación y contamos con numerosísimas imágenes de ellos, otros han merecido menor atención.

En fin, si -como dicen- detrás de todo gran hombre hay una gran mujer, no cabe duda de que detrás de Odiseo no falta el influjo de una figura femenina. Todas ellas contribuyen a resaltar la fuerza del héroe, pues sin su presencia no habría conseguido nunca su objetivo. Atenea, empeñada en lograr el feliz regreso para su protegido, Nausica, que le acerca a su destino, Calipso y Circe, las dos enamoradas de Ulises, que, llegado el momento se resignan a perder a su amado y actúan a su favor... Incluso Escila y las Sirenas ¿no ha sido el vencerlas - cosa que ningún otro mortal ha hecho- un paso más hacia su gloria de héroe?

Es que él es -en palabras de Homero- el divino Ulises, el hijo de Laertes, cuya fama llega hasta el mismo cielo.

\section{BIBLIOGRAFIA GENERAL}

D. Buitron-B. COHEN, The Odyssey and Ancient Art: An epic in Word and Image, Annandale on Hudson 1992.

F. Brommer, Odysseus: Die Taten und Leiden des Helden in antiker Kunst und Literatur, Darmstadt 1983.

B. COHEN (ed.), The Distaff Side. Representing the female in Homer's Odyssey, Nueva York \& Oxford 1995.

J.E. HARRISON, Myths of the Odyssey in Art and Literature, Londres 1882.

Lexikon Iconographicum Mythologiae Classicae, Zurich-Munich 1981-1997.

A.SHAPIRO, Myth into Art, Londres \& Nueva York 1994.

O. Touchefeu-Mernier, Thèmes Odysséens dans l'art antique, París 1968.

Ulisse. II Mito e la memoria, Ex.Cat. Roma. Palazzo delle Esposizioni 1996. 